\title{
Economic Evaluation of Front Line Demonstrations on Black Gram in Birbhum District of West Bengal
}

\author{
Prabuddha Ray*, Subrata Mandal, Sourav Mondal and Palash Ankure
}

Rathindra Krishi Vigyan Kendra, Palli Siksha Bhavana (Institute of Agriculture), Visva-Bharati, Sriniketan, Birbhum - 731236, West Bengal, India

Corresponding author: prabuddha_ray1@rediffmail.com

\begin{abstract}
The present study indicated that in 1997-98, the numbers of demonstrations, area covered, average percentage of yield increase over the local check variety and numbers of farmers adopting the new variety except the already existing FLD partner farmers reached a point of high. However, the B: C ratio was highest in 1995-96. From then the performances of the demonstrations on black gram took a downhill trend till 2010-11. This situation prevailed mainly due to presence of improved high yielding local variety lowering the average increase of yield of the demonstrated variety over the local variety, increased cost of cultivation and stagnant market prices mainly due to absence of local dal milling units. From 2013-14 and especially after the launch of the cluster FLD programme, the performances are being brightened up. This achievement has been possible mainly due to choice of the high yielding improved varieties like WBU - 108 and WBU - 109 which are less than 10 years old after its official release, disseminating the pulse production technology through an integrated approach involving improved seeds, micro-nutrients and Rhizobium inoculations and integrated plant protection technologies and establishment of mini-dal processing units throughout the district with central sector assistance and enhanced minimum support price as announced by Government of India.
\end{abstract}

Keywords: Front line demonstration, black gram, minimum support price, West Bengal

India is one of the major pulse producing countries contributing about 33 per cent of world area and 25 per cent of world production of pulses. Pulses are also an important component of Indian agricultural economy next to food grains and oilseeds in terms of acreage, production and economic value. However, an alarming fact is that there is a stark decline in the availability of pulses in the country from $69 \mathrm{~g} /$ capita/day in 1961 to $33 \mathrm{~g} /$ capita/day in 2009-10 [Indian Council of Medical Research (ICMR) recommends $65 \mathrm{~g} /$ day/capita]. To overcome the problem of protein energy malnutrition, a minimum of $50 \mathrm{~g}$ pulses/capita/day should be available in addition to other sources of protein. Thus, to make the nation pulse sufficient, average yield level has to increase substantially up to $1200 \mathrm{~kg} / \mathrm{ha}$ by 2020 .

However, In India, the irrigated area under pulses was only 12 per cent, while under wheat and paddy; it was more than 60 per cent of the total area.
Gupta (2001) in a Comprehensive Agro-Economic Research Centres study worked on economics of pulses production and identification of constraints in raising their production covering 13 states under the 10 Agro-Economic Research Centres and the study was based on the agricultural year of 1996-97. He found that unlike other food-grains like paddy and wheat, pulses were still relegated to the status of an inferior crop and despite the price rises in produced pulses, area under pulses was found to have nearly stagnated. The major constraints inhibiting productivity enhancement of pulses were lack of information about improved technology; lower adoption of Rhizobium culture; scant availability of high-yielding, disease resistant and drought resistant improved variety of seeds suitable for different climatic conditions; lower profits in production of pulses vis-à-vis competing crops; and high variability in yields (Gupta, 2001). 
Table 1: Import of pulse in West Bengal and India (2010-11)

\begin{tabular}{ccccccc}
\hline State & $\begin{array}{c}\text { Population } \\
\text { (M) }\end{array}$ & $\begin{array}{c}\text { Area } \\
\text { (Mha) }\end{array}$ & Production (Mt) & $\begin{array}{c}\text { Productivity } \\
\text { (Kg./ha) }\end{array}$ & Requirement (Mt) & Import (Mt) \\
\hline West Bengal & 91.3 & 0.18 & 0.15 & 833 & 1.42 & 1.27 \\
India & 1175 & 23.50 & 14.60 & 689 & 18.33 & 3.73 \\
\hline
\end{tabular}

Source: Dept. of Agriculture and Cooperation, Ministry of Agriculture, Govt. of India

Table 2: Projected import of pulse in West Bengal and India by 2050

\begin{tabular}{cccccccc}
\hline State & $\begin{array}{c}\text { Population } \\
\text { (M) }\end{array}$ & $\begin{array}{c}\text { Additional Area Total Area } \\
\text { over Year 2010- } \\
\text { 11 (Mha) }\end{array}$ & $\begin{array}{c}\text { Production } \\
\text { (Mha) }\end{array}$ & $\begin{array}{c}\text { Productivity } \\
\text { (Kg./ha) }\end{array}$ & $\begin{array}{c}\text { Requirement } \\
\text { (Mt) }\end{array}$ & $\begin{array}{c}\text { Import } \\
\text { (Mt) }\end{array}$ \\
\hline $\begin{array}{c}\text { West Bengal } \\
\text { India }\end{array}$ & 127.00 & 0.003 & 0.183 & 0.27 & 1450.9 & 2.09 & 1.82 \\
\hline
\end{tabular}

Source: Singh et al. (2013)

The farmers fail to benefit from enhanced market prices of pulses due to lack of direct access to processing and marketing facilities. Non-availability of disease and drought resistant varieties of seeds suitable for different climates, inadequate input subsidy, ill functioning price support mechanism, lack of knowledge about the improvement in the harvest and post harvest technology, and poor modern storage facilities, are the main constraints to boost pulses production.

As a result of these factors, both productivity and production is not up to the potential mark leading to the mismatch between supply and demand of pulses forcing the shooting up of the pulse prices. To meet the demand for pulses, India has been importing a large quantity of pulses in recent years. The country is importing pulses to the tune of 2.5-3.5 million tonnes every year for meeting the demand of the growing population. The import of pulse crops increased from $0.38 \mathrm{Mt}$ in 1993 to $2.8 \mathrm{Mt}$ in 2008 (about 16 per cent of the domestic consumption). The situation is not much different for the State of West Bengal also (Tables 1 and 2).

According to Sekhon et al. (2009) the demand for pulses for household consumption is projected at 15.51 million tonnes in 2011, 20.16 million tonnes in 2021 and 25.73 million tonnes in 2030 at a 4 per cent rate of growth of Gross Domestic Product (GDP) at factor cost of 2004-05 prices. However, at a higher growth rate of GDP of 7 per cent at the factor cost of 2004-05 prices, the total demand for pulses becomes 38.97 million tonnes in 2030 . The projection of Singh et al. (2013) is given in the Table 2. If this is to be materialized in the case of West Bengal, the projected decadal growth in pulse productivity is presented in Table 3.

Table 3: Projected decadal growth in pulse productivity in West Bengal

\begin{tabular}{cc}
\hline Year & Productivity (kg. / ha) \\
\hline $2010-11$ & 833.3 \\
$2020-21$ & 950.3 \\
$2030-31$ & 1272.4 \\
$2050-51$ & 1450.9 \\
\hline
\end{tabular}

Source: Singh et al. (2013)

If West Bengal is to achieve the projected decadal growth rate, then the district of Birbhum is to play an important role. Birbhum district is one of the potential pulses growing district of West Bengal is presented in Table 4.

Table 4: Area, production and productivity of pulses in Birbhum district

\begin{tabular}{cccc}
\hline Year & $\begin{array}{c}\text { Area } \\
\text { (`000 ha) }\end{array}$ & $\begin{array}{c}\text { Production } \\
\text { (`000 tonnes) }\end{array}$ & $\begin{array}{c}\text { Productivity } \\
\text { (kg. / ha) }\end{array}$ \\
\hline $1980-81$ & 28.9 & 14.4 & 498 \\
$1990-91$ & 8.6 & 5.4 & 626 \\
$1998-99$ & 9.6 & 8.6 & 903 \\
$1999-00$ & 10.8 & 10.5 & 974 \\
$2000-01$ & 20.2 & 16.8 & 832 \\
$2001-02$ & 18.7 & 17.9 & 956 \\
$2002-03$ & 15.4 & 13.6 & 883
\end{tabular}




\begin{tabular}{cccc}
$2003-04$ & 16.5 & 18.0 & 1092 \\
$2004-05$ & 15.7 & 12.4 & 788 \\
$2005-06$ & 18.5 & 14.5 & 785 \\
$2006-07$ & 20.7 & 16.0 & 773 \\
$2007-08$ & 17.8 & 18.2 & 1019 \\
$2008-09$ & 16.3 & 15.3 & 937 \\
$2009-10$ & 15.8 & 14.1 & 891 \\
$2010-11$ & 17.0 & 17.1 & 1004 \\
\hline
\end{tabular}

Source: Dept. of Agriculture, Govt. of West Bengal.

In this scenario, the emphasis has to be given mainly on productivity, obviously because of the well documented fact that not much scope of area expansion in this region of the country exists, leaving the main focus on improving productivity improvement through better agronomic management and technological advancement (GoI, 20212; Singh et al. 2012 and Reddy, 2009).

In Birbhum district, black gram is one of the leading pulse crops over the years. However, a characteristic feature of the district pulse production scenario is that the productivity of black gram is much higher in summer season under irrigated condition than that of rabi season and this is also supported by the data presented in Table 5. So, there is scope to introduce the black gram crop as a summer crop in Birbhum district especially in the irrigated areas replacing prevalent non-remunerative crops.

Table 5: Area, production and productivity of black gram in Birbhum district

\begin{tabular}{ccccc}
\hline Year & $\begin{array}{c}\text { Area } \\
\text { (ha) }\end{array}$ & $\begin{array}{c}\text { Production } \\
\text { (MT) }\end{array}$ & $\begin{array}{c}\text { Productivity } \\
\text { (kg. / ha) }\end{array}$ & Season \\
\hline $2011-12$ & 375 & 294.375 & 785 & Summer \\
& 1240 & 505.920 & 408 & Rabi \\
$2012-13$ & 450 & 362.250 & 805 & Summer \\
& 1321 & 663.142 & 502 & Rabi \\
$2013-14$ & 520 & 449.800 & 865 & Summer \\
& 1052 & 654.344 & 622 & Rabi \\
$2014-15$ & 660 & 584.199 & 885.15 & Summer \\
& 1085 & 694.400 & 640 & Rabi \\
$2015-16$ & 625 & 596.9375 & 955.10 & Summer \\
& 1125 & 748.125 & 665 & Rabi \\
\hline
\end{tabular}

Source: Dept. of Agriculture, Govt. of West Bengal.

In view of the above, the present study has been undertaken to make an economic evaluation of front line demonstrations on black gram in Birbhum District of West Bengal.

\section{MATERIALS AND METHODS}

The study has been conducted based on both primary and secondary data. The secondary data has been collected from different published sources. The primary data has been collected from the FLDs on black gram conducted by the Rathindra KVK, Visva-Bharati from 1995-96 to 2016-17. The primary data were collected from the respondents through personal interview method on pre-tested schedules. A complete enumeration of 639 numbers of FLD partner farmers on black gram was the sample unit of the study. Relevant analytical techniques have been applied to fulfil the various objectives of the study. For analysis of data, cost concepts (establishment cost, fixed cost, variable cost and total cost) and economic efficiency measures viz. Benefit-Cost Ratio were employed.

\section{RESULTS AND DISCUSSION}

From Table 6 and graph 1, it is to be clearly noted that in 1997-98, the numbers of demonstrations, area covered and average percentage of yield increase over the local check variety and numbers of farmers adopting the new variety except the already existing FLD partner farmers was highest. However, the average B: C ratio was highest in 1995-96. From then on, the performances of the demonstrations on black gram took a downhill trend till 2010-11. This situation prevailed mainly due to presence of improved high yielding local variety as local check variety lowering the average increase of yield of the demonstrated variety over the local check variety, increased cost of cultivation and stagnant market prices mainly caused by absence of local dal milling units.

From 2013-14 and especially after the launch of the Cluster FLD programme on pulses by the Ministry of Agriculture and Farmers' Welfare, Govt. of India and Indian Council of agricultural Research (ICAR) in 2015-16, the performances are being brightened up year by year with the results of the last year viz. 2016-17 showing an impressive number of demonstrations (99) covering 20 hectares of land giving an average 57.0 percentage point increase of yield over the local check variety with a significant B: C Ratio of 3.08 resulting in adoption of the new variety by 197 numbers of farmers in addition to the already existing FLD partner farmers and this numbers of farmers adopting the new variety 
Table 6: Area and performances of FLDs on black gram

\begin{tabular}{cccccc}
\hline Year & $\begin{array}{c}\text { No. of } \\
\text { Demonstrations }\end{array}$ & $\begin{array}{c}\text { Area } \\
\text { Covered } \\
\text { (ha) }\end{array}$ & $\begin{array}{c}\text { Average Percentage } \\
\text { of Yield Increase over } \\
\text { Local Check }\end{array}$ & $\begin{array}{c}\text { Average B: C } \\
\text { Ratio }\end{array}$ & $\begin{array}{c}\text { Farmer to Farmer Extension (No. } \\
\text { of Farmers adopted the New } \\
\text { Variety except the FLD Partner } \\
\text { Farmers) }\end{array}$ \\
\hline $1995-96$ & 65 & 2.0 & 53 & 3.92 & 36 \\
$1997-98$ & 150 & 7.0 & 56 & 3.75 & 90 \\
$1998-99$ & 50 & 3.0 & 54 & 3.50 & 30 \\
$2007-08$ & 39 & 10.0 & 62 & 3.00 & 24 \\
$2008-09$ & 39 & 10.0 & 58 & 3.42 & 24 \\
$2009-10$ & 25 & 5.0 & 59 & 3.38 & 16 \\
$2010-11$ & 25 & 5.0 & 20 & 2.97 & 18 \\
$2013-14$ & 73 & 9.0 & 20 & 2.71 & 57 \\
$2015-16$ & 74 & 10.0 & 19 & 2.48 & 80 \\
$2016-17$ & 99 & 20.0 & 57 & 3.08 & 197 \\
\hline
\end{tabular}

except the already existing FLD partner farmers was highest in this particular year.

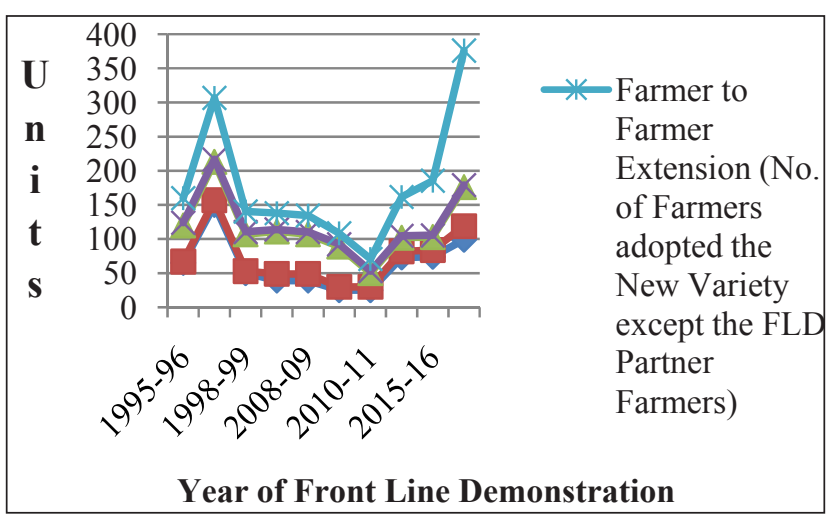

Graph 1: Area and performances of FLDs on black gram

Table 7: Minimum support price of black gram

\begin{tabular}{cc}
\hline Year & ₹ / Quintal \\
\hline $1995-96$ & 800.00 \\
$1997-98$ & 900.00 \\
$1998-99$ & 960.00 \\
$2007-08$ & $1740.00^{*}$ \\
$2008-09$ & 2520.00 \\
$2009-10$ & 2520.00 \\
$2010-11$ & 2900.00 \\
$2013-14$ & 4300.00 \\
$2015-16$ & $4625.00^{\wedge}$ \\
$2016-17$ & $5000.00^{\wedge \wedge}$ \\
\hline
\end{tabular}

N.B.: - * Bonus of ₹ 40.00 per quintal; ^ Including Bonus of ₹ 200.00 per quintal; $\wedge \wedge$ Including Bonus of $₹ 425.00$ per quintal.

Source: Ministry of Agriculture and Farmers' Welfare, Govt. of India and http://www.farmer.gov.in/mspstatements.aspx
This significant achievement has been possible mainly due to choice of the high yielding improved varieties like WBU - 108 and WBU - 109 which are less than 10 years old after its official release, disseminating the pulse production technology through an integrated approach involving improved seeds, micro-nutrients and Rhizobium inoculations and integrated plant protection technologies and establishment of mini-dal processing units throughout the district with central sector assistance and enhanced minimum support price (MSP) as announced by Govt. of India.

Table 8: Growth of integrated cereal and pulse processing units in Birbhum district

(Numbers of Units)

\begin{tabular}{cccccc}
\hline $\mathbf{2 0 0 7 - 0 8}$ & $\mathbf{2 0 0 8 - 0 9}$ & $\mathbf{2 0 0 9 - 1 0}$ & $\mathbf{2 0 1 0 - 1 1}$ & $\mathbf{2 0 1 1 - 1 2}$ & Total \\
\hline 05 & 07 & 05 & 06 & 04 & 27 \\
\hline
\end{tabular}

Source: Food Processing Industries Survey of Birbhum District, 2012-13 (IWIN/1213/D/SR/R0/007)

Internet Source: www.myenterprise.wb.gov.in/.../Download?.../ Food\%20Processing\%20Industries\%20...1.

One of the positive factors for improvement of the performances of the FLDs on black gram in terms of economics is the raising of the minimum support prices (MSPs) for black gram over the years by Govt. of India. Following the recommendations of the Committee on Agricultural Costs and Prices (CACP) in the last financial year i.e. 2016-17, it stood at an impressive price of ₹ 5,000.00/quintal including ₹ 425.00/quintal bonus announced by Govt. of India. 
This up-ward trend in MSP as depicted in the Table - 7 has certainly an effect on the increase in net return and B: C Ratio in cultivation of black gram.

In Birbhum district, over the years, a number of integrated cereal and pulse processing units have been established by private, co-operative and Farmer Producers' Organizations (FPOs) with financial and technological back-stopping by various agencies as depicted in the Table 8.

These pulse processing units besides providing more than 260 numbers of persons direct employment, they are also providing a more accessible potential market for selling the pulse produced by the farmers of the district as well as processing the pulses for the home consumptions of the farmers also. It has also a positive effect of the economic performances of the FLDs on black gram.

\section{CONCLUSION}

The performances of the front line demonstrations can be further strengthened through continuation of the cluster approach of organization of demonstrations and dissemination of integrated package of practices of the technologies regarding black gram cultivation as is now being followed in the cluster front line demonstration programmes on pulses by the Ministry of Agriculture and Farmers' Welfare, Govt. of India and Indian Council of Agricultural Research through technological and critical inputs (integrated inputs like improved seeds, organic and bio-fertilizers, micro-nutrients, herbicides etc.) back-stooping by the concerned Krishi Vigyan Kendras. Utmost importance must be given on choosing of the demonstrated high yielding improved varieties like WBU - 108 and WBU - 109 which are less than 10 years old after its official release, disseminating the pulse production technology through an integrated approach involving improved seeds, micro-nutrients and Rhizobium inoculations and integrated plant protection technologies and establishment of minidal processing units throughout the district with central sector assistance and enhanced MSP.

Another important point is to be mentioned that the productivity of black gram is much higher in summer season under irrigated condition than that of rabi season in Birbhum, West Bengal. So, there is scope to introduce the black gram crop as a summer crop in Birbhum district especially in the irrigated areas replacing prevalent non-remunerative crops.

\section{REFERENCES}

GoI, 2012. Data Base on Indian Agriculture, Department of Agriculture and Cooperation, Ministry of Agriculture, Govt. of India.

Gupta, S.K. 2001. Economics of Pulses Production and Identification of Constraints in raising their Production (a Consolidated Report of AERC studies), Ad-hoc Study undertaken by the Agro Economic Research Centre, Jawaharlal Nehru Krishi Vishwa Vidyalaya, Madhya Pradesh, (79): 177.

Reddy, A.A. 2004. Consumption Pattern, Trade and Production Potential of Pulses, Economic \& Political Weekly, XL(48): $54-60$.

Reddy, S.S. and Ram, R.P. 2010. Agricultural Finance and Management, Oxford and IBH Publishing Co. Pvt .Ltd., New Delhi, pp. 126 - 127.

Sekhon, M.K., Sidhu, M.S. and Dhaliwal, T.K. 2009. Demand Projections and Farmers' Perceptions about Pulses Production in Punjab, Agricultural Situation in India, 65(12): 731 - 738.

Singh, A.K., Manibhushan, Bhatt, B.P., Singh, K.M. and Upadhaya, A., 2013. An Analysis of Oilseeds and Pulses Scenario in Eastern India during 2050-51, Journal of Agricultural Sciences, 5(1): 241 - 249.

Singh, A.K., Sangle, U.R., and Bhatt, B.P. 2012. Mitigation of imminent climate change and enhancement of agricultural system productivity through efficient carbon sequestration and improved production technologies, Indian Farming, 61(10): $5-9$. 
